Article

\title{
Arsenates of Divalent Metals Comprising Arsenic Acid-An Update
}

\author{
Matthias Weil (D) \\ Institute for Chemical Technologies and Analytics, Division of Structural Chemistry, TU Wien, \\ Getreidemarkt 9/164-SC, A-1060 Vienna, Austria; Matthias.Weil@tuwien.ac.at
}

Received: 6 September 2019; Accepted: 1 October 2019; Published: 9 October 2019

\begin{abstract}
Divalent metal oxidoarsenates $(\mathrm{V})$ with compositions $M\left(\mathrm{H}_{2} \mathrm{AsO}_{4}\right)_{2}\left(\mathrm{H}_{3} \mathrm{AsO}_{4}\right)_{2}(\mathrm{M}=\mathrm{Mg}, \mathrm{Mn}$, $\mathrm{Co}, \mathrm{Ni}), M\left(\mathrm{HAsO}_{4}\right)\left(\mathrm{H}_{3} \mathrm{AsO}_{4}\right)\left(\mathrm{H}_{2} \mathrm{O}\right)_{0.5}(\mathrm{M}=\mathrm{Mn}, \mathrm{Cd})$ and $\mathrm{Zn}\left(\mathrm{HAsO}_{4}\right)\left(\mathrm{H}_{3} \mathrm{AsO}_{4}\right)$ were obtained from solutions containing an excess of arsenic acid. Single crystal $\mathrm{X}$-ray diffraction revealed isotypism of the $M\left(\mathrm{H}_{2} \mathrm{AsO}_{4}\right)_{2}\left(\mathrm{H}_{3} \mathrm{AsO}_{4}\right)_{2}(\mathrm{M}=\mathrm{Mg}, \mathrm{Mn}, \mathrm{Co}, \mathrm{Ni})$ structures with the known $\mathrm{Cu}$ and $\mathrm{Zn}$ members of this series whereas $M\left(\mathrm{HAsO}_{4}\right)\left(\mathrm{H}_{3} \mathrm{AsO}_{4}\right)\left(\mathrm{H}_{2} \mathrm{O}\right)_{0.5}(\mathrm{M}=\mathrm{Mn}, \mathrm{Cd})$ and $\mathrm{Zn}\left(\mathrm{HAsO}_{4}\right)\left(\mathrm{H}_{3} \mathrm{AsO}_{4}\right)$ crystallize in novel structure types. The two isotypic $M\left(\mathrm{HAsO}_{4}\right)\left(\mathrm{H}_{3} \mathrm{AsO}_{4}\right)\left(\mathrm{H}_{2} \mathrm{O}\right)_{0.5}(M=\mathrm{Mn}, \mathrm{Cd})$ structures are closely related with that of $\mathrm{Zn}\left(\mathrm{HAsO}_{4}\right)\left(\mathrm{H}_{3} \mathrm{AsO}_{4}\right)$. Both comprise undulating centrosymmetric ${ }_{\propto}^{1}\left[\mathrm{MO}_{4 / 2} \mathrm{O}_{2 / 1}\right]$ chains that share corners with $\mathrm{HAsO}_{4}{ }^{2-}$ tetrahedra and $\mathrm{H}_{3} \mathrm{AsO}_{4}$ tetrahedra to build up layers extending along (001). Intermediate water molecules (occupancy 0.5) link adjacent layers in the water-containing compound whereas the linkage in the Zn-compound is mediated by weak hydrogen bonding interactions between the layers. Results of a quantitative comparison between all known structures of the $M\left(\mathrm{H}_{2} \mathrm{XO}_{4}\right)_{2}\left(\mathrm{H}_{3} X_{\mathrm{O}_{4}}\right)_{2}(M=\mathrm{Mg}, \mathrm{Mn}, \mathrm{Co}, \mathrm{Ni}, \mathrm{Cu}, \mathrm{Zn} ; \mathrm{X}=\mathrm{P}$, As) series as well as between the two $M\left(\mathrm{HAsO}_{4}\right)\left(\mathrm{H}_{3} \mathrm{AsO}_{4}\right)\left(\mathrm{H}_{2} \mathrm{O}\right)_{0.5}(M=\mathrm{Mn}, \mathrm{Cd})$ structures are presented.
\end{abstract}

Keywords: arsenates; arsenic acid; crystal structure; hydrogen bonding; isotypism; structure comparison

\section{Introduction}

Inorganic phosphates or arsenates of divalent metals with the corresponding free acid as structure units are restricted to a handful of compounds. Most probably, $\mathrm{Zn}\left(\mathrm{H}_{2} \mathrm{PO}_{4}\right)_{2}\left(\mathrm{H}_{3} \mathrm{PO}_{4}\right)_{2}$ was one of the first of such phases ever reported [1], however without giving structural details at that time. More than three decades later, the crystal structure of $\mathrm{Co}\left(\mathrm{H}_{2} \mathrm{PO}_{4}\right)_{2}\left(\mathrm{H}_{3} \mathrm{PO}_{4}\right)_{2}$ was determined, providing full details of the hydrogen bonding scheme in the structure [2], and later reported as being isotypic with the zinc phase [3]. Approximately at the same time, the first arsenate phase $\mathrm{CdH}_{10}\left(\mathrm{AsO}_{4}\right)_{4}$ (or $\mathrm{Cd}\left(\mathrm{H}_{2} \mathrm{AsO}_{4}\right)_{2}\left(\mathrm{H}_{3} \mathrm{AsO}_{4}\right)_{2}$ ) was structurally determined but without localization of $\mathrm{H}$ positions [4], claiming isotypism of the $\mathrm{Cd}$ member with structures of the series $M\left(\mathrm{H}_{2} \mathrm{AsO}_{4}\right)_{2}\left(\mathrm{H}_{3} \mathrm{AsO}_{4}\right)_{2}(M=\mathrm{Mg}$, $\mathrm{Mn}, \mathrm{Co}, \mathrm{Ni}, \mathrm{Cu}$ and $\mathrm{Zn})$. However, the isotypic relationship between $\mathrm{CdH}_{10}\left(\mathrm{AsO}_{4}\right)_{4}$ and the $M\left(\mathrm{H}_{2} \mathrm{AsO}_{4}\right)_{2}\left(\mathrm{H}_{3} \mathrm{AsO}_{4}\right)_{2}$ series was questioned some years later during structure determination of the copper(II) phase $\mathrm{Cu}\left(\mathrm{H}_{2} \mathrm{AsO}_{4}\right)_{2}\left(\mathrm{H}_{3} \mathrm{AsO}_{4}\right)_{2}$ [5]. Next to the previously reported $\mathrm{Zn}$ representative [6], the two structures are the only members of the $M\left(\mathrm{H}_{2} \mathrm{AsO}_{4}\right)_{2}\left(\mathrm{H}_{3} \mathrm{AsO}_{4}\right)_{2}$ series for which detailed structure data, including $\mathrm{H}$ atom positions, have been determined so far.

The current study was devoted to crystallize other members of the $M\left(\mathrm{H}_{2} \mathrm{AsO}_{4}\right)_{2}\left(\mathrm{H}_{3} \mathrm{AsO}_{4}\right)_{2}$ series $(M=\mathrm{Mg}, \mathrm{Mn}, \mathrm{Co}, \mathrm{Ni})$ to achieve detailed structural data from single crystal X-ray diffraction with the purpose to prove isotypism and to quantify structural relationships between them with the aid of the program compstru [7]. Next to the four $M\left(\mathrm{H}_{2} \mathrm{AsO}_{4}\right)_{2}\left(\mathrm{H}_{3} \mathrm{AsO}_{4}\right)_{2}(M=\mathrm{Mg}, \mathrm{Mn}, \mathrm{Co}, \mathrm{Ni})$ members, three other arsenates with additional arsenic acid moieties, viz. $M\left(\mathrm{HAsO}_{4}\right)\left(\mathrm{H}_{3} \mathrm{AsO}_{4}\right)\left(\mathrm{H}_{2} \mathrm{O}\right)_{0.5}(M=\mathrm{Mn}, \mathrm{Cd})$ and $\mathrm{Zn}\left(\mathrm{HAsO}_{4}\right)\left(\mathrm{H}_{3} \mathrm{AsO}_{4}\right)$, were obtained during this study for the first time and were structurally characterized by single crystal $\mathrm{X}$-ray diffraction. 


\section{Results and Discussion}

\subsection{Crystal Structures of the $M\left(\mathrm{H}_{2} \mathrm{AsO}_{4}\right)_{2}\left(\mathrm{H}_{3} \mathrm{AsO}_{4}\right)_{2}$ Series $(\mathrm{M}=\mathrm{Mg}, \mathrm{Mn}, \mathrm{Co}, \mathrm{Ni})$}

The $M\left(\mathrm{H}_{2} \mathrm{AsO}_{4}\right)_{2}\left(\mathrm{H}_{3} \mathrm{AsO}_{4}\right)_{2}(M=\mathrm{Mg}, \mathrm{Mn}, \mathrm{Co}, \mathrm{Ni})$ crystal structures are isotypic with $\mathrm{Co}\left(\mathrm{H}_{2} \mathrm{PO}_{4}\right)_{2}\left(\mathrm{H}_{3} \mathrm{PO}_{4}\right)_{2}$ [2], $\mathrm{Cu}\left(\mathrm{H}_{2} \mathrm{AsO}_{4}\right)_{2}\left(\mathrm{H}_{3} \mathrm{AsO}_{4}\right)_{2}$ [5] and $\mathrm{Zn}\left(\mathrm{H}_{2} \mathrm{AsO}_{4}\right)_{2}\left(\mathrm{H}_{3} \mathrm{AsO}_{4}\right)_{2}$ [6]. Since for all of the latter compounds a detailed structure description has already been given, only the most important features of this structure type are briefly depicted here.

The divalent metal cations $M$ are located on an inversion center (Wyckoff position $1 a$ ). They are surrounded by six oxygen atoms in the form of a slightly distorted octahedron. Four oxygen atoms (O7, $\mathrm{O} 5$ and their symmetry-related counterparts) belong to the $\mathrm{O}$ atoms of the $\mathrm{H}_{2} \mathrm{AsO}_{4}{ }^{-}$group (As2) and make up the equatorial plane, while the $\mathrm{H}_{3} \mathrm{AsO}_{4}$ group (As1) provides two oxygen atoms (O3 and its symmetry-related counterpart) in axial positions with the longest $M-O$ distance in the octahedron (Figure 1; Table 1).

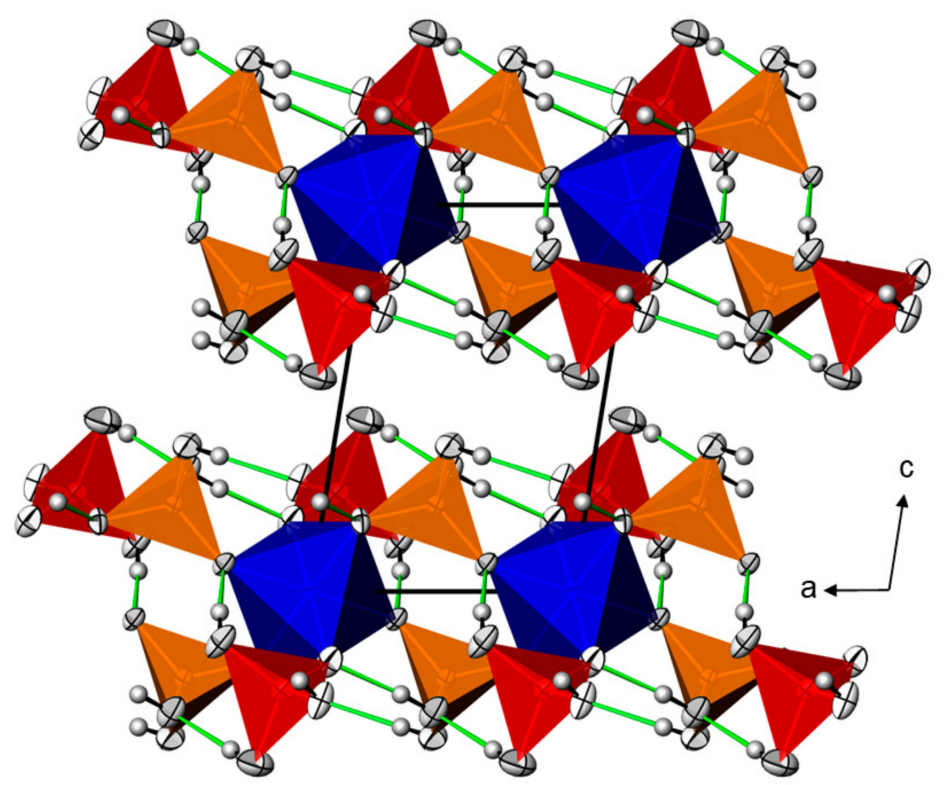

Figure 1. Representative for the $M\left(\mathrm{H}_{2} \mathrm{XO}_{4}\right)_{2}\left(\mathrm{H}_{3} \mathrm{XO}_{4}\right)_{2}$ series, the crystal structure of $\mathrm{Mn}\left(\mathrm{H}_{2} \mathrm{AsO}_{4}\right)_{2}\left(\mathrm{H}_{3} \mathrm{AsO}_{4}\right)_{2}$ is given in a projection along (010). Displacement ellipsoids are drawn at the $90 \%$ probability level. $\mathrm{H}_{2} \mathrm{AsO}_{4}{ }^{-}$tetrahedra (As2) are orange, $\mathrm{H}_{3} \mathrm{AsO}_{4}$ tetrahedra (As1) are red, $\mathrm{MnO}_{6}$ octahedra are blue; $\mathrm{H}$ atoms are displayed as grey spheres of arbitrary radius. $\mathrm{O} \cdots \mathrm{H}$ hydrogen bonds are shown as green lines.

Individual $M-\mathrm{O}$ bond lengths and their mean values are typical for the corresponding metal cation. In accordance with the largest ionic radius of $\mathrm{Mn}$ of all four $M^{I I}$ cations $(M=\mathrm{Mg}, \mathrm{Mn}, \mathrm{Co}, \mathrm{Ni})$ [8], Mn exhibits the longest $M-\mathrm{O}$ bonds. Neighboring metal cations are linked into chains along (100) by bridging $\mathrm{H}_{2} \mathrm{AsO}_{4}{ }^{-}$groups; the $\mathrm{H}_{3} \mathrm{AsO}_{4}$ group is attached to the chains and has no bridging character. An intricate network of strong to medium-strong hydrogen bonds (Table 2) connects the chains into layers extending along (010) (Figure 1 ) whereby all $\mathrm{O}$ atoms that do not bond to the $M$ cations carry a hydrogen atom. Hydrogen bonds of remarkable strengths between the layers do not exist. 
Table 1. Selected bond lengths $/ \AA$, angles $/{ }^{\circ}$ with estimated standard deviations in parentheses, and bond valence parameters (BVS)/valence units. Averaged values (av.) are given in the last line of each column.

\begin{tabular}{|c|c|c|c|c|c|c|c|c|c|c|c|c|c|}
\hline \multicolumn{5}{|c|}{$\mathrm{Mn}\left(\mathrm{HAsO}_{4}\right)\left(\mathrm{H}_{3} \mathrm{AsO}_{4}\right)\left(\mathrm{H}_{2} \mathrm{O}\right)_{0.5}$} & \multicolumn{5}{|c|}{$\mathrm{Cd}\left(\mathrm{HAsO}_{4}\right)\left(\mathrm{H}_{3} \mathrm{AsO}_{4}\right)\left(\mathrm{H}_{2} \mathrm{O}\right)_{0.5}$} & \multicolumn{4}{|c|}{$\mathrm{Zn}\left(\mathrm{HAsO}_{4}\right)\left(\mathrm{H}_{3} \mathrm{AsO}_{4}\right)$} \\
\hline \multirow[t]{7}{*}{ Mn1 } & - & $\mathrm{O} 3$ & $2.149(2)$ & & $\mathrm{Cd} 1$ & - & $\mathrm{O} 3$ & $2.242(3)$ & & Zn1 & $\mathrm{O} 3$ & $2.031(3)$ & \\
\hline & - & O5 & $2.162(3)$ & & & - & O5 & $2.253(4)$ & & & $\mathrm{O} 7$ & $2.048(3)$ & \\
\hline & - & O7 & $2.186(3)$ & & & - & $\mathrm{O} 7$ & $2.273(3)$ & & & $\mathrm{O} 2$ & $2.123(4)$ & \\
\hline & - & O7 & $2.202(3)$ & & & - & O7 & $2.307(3)$ & & & O5 & $2.127(4)$ & \\
\hline & - & $\mathrm{O} 2$ & $2.229(3)$ & & & - & $\mathrm{O} 2$ & $2.307(3)$ & & & O7 & $2.180(4)$ & \\
\hline & - & $\mathrm{O} 3$ & $2.229(3)$ & & & - & $\mathrm{O} 3$ & $2.314(3)$ & & & $\mathrm{O} 3$ & $2.204(4)$ & \\
\hline & & av. & 2.19 & & & & av. & 2.28 & & & av. & 2.12 & \\
\hline \multirow[t]{5}{*}{ As1 } & - & O7 & $1.666(3)$ & & As1 & - & O7 & $1.663(3)$ & & As1 & $\mathrm{O} 7$ & $1.669(3)$ & \\
\hline & - & $\mathrm{O} 3$ & $1.673(3)$ & & & - & $\mathrm{O} 3$ & $1.672(3)$ & & & $\mathrm{O} 3$ & $1.673(3)$ & \\
\hline & - & $\mathrm{O} 2$ & $1.698(3)$ & & & - & $\mathrm{O} 2$ & $1.696(3)$ & & & $\mathrm{O} 2$ & $1.690(4)$ & \\
\hline & - & $\mathrm{O} 1$ & $1.708(3)$ & & & - & O1 & $1.714(4)$ & & & $\mathrm{O} 1$ & $1.710(4)$ & \\
\hline & & av. & 1.686 & & & & av. & 1.686 & & & av. & 1.689 & \\
\hline \multirow[t]{5}{*}{ As2 } & - & $\mathrm{O} 5$ & $1.654(3)$ & & As2 & - & O5 & $1.649(4)$ & & As2 & $\mathrm{O} 5$ & $1.668(4)$ & \\
\hline & - & $\mathrm{O} 4$ & $1.666(3)$ & & & - & $\mathrm{O} 4$ & $1.670(4)$ & & & $\mathrm{O} 4$ & $1.673(4)$ & \\
\hline & - & $\mathrm{O} 6$ & $1.692(5)$ & & & - & O6 & $1.686(7)$ & & & O8 & $1.687(4)$ & \\
\hline & - & $\mathrm{O} 8$ & $1.705(5)$ & & & - & O8 & $1.702(6)$ & & & O6 & $1.698(5)$ & \\
\hline & & av. & 1.680 & & & & av. & 1.677 & & & av. & 1.682 & \\
\hline \multicolumn{14}{|c|}{ BVS } \\
\hline \multicolumn{5}{|c|}{$\begin{array}{c}\text { Mn1 2.03, As1 5.01, As2 5.11, } \\
\text { O1 1.18, O2 1.52, O3 1.98, } \\
\text { O4 1.33, O5 1.73, O6 1.23, } \\
\text { O7 2.00, O8 1.19. }\end{array}$} & \multicolumn{5}{|c|}{$\begin{array}{c}\text { Cd1 2.16, As1 5.01, As2 5.15, } \\
\text { O1 1.16, O2 1.55, O3 2.03, } \\
\text { O4 1.31, O5 1.78, O6 1.25, } \\
\text { O7 2.04, O8 1.20. }\end{array}$} & \multicolumn{4}{|c|}{$\begin{array}{c}\text { Zn1 1.98, As1 5.02, As2 5.07, O1 1.17, } \\
\text { O2 1.56, O3 1.97 O4 1.30, O5 1.64, } \\
\text { O6 1.21, O7 1.99, O8 1.25. }\end{array}$} \\
\hline \multicolumn{4}{|c|}{$\mathrm{Mg}\left(\mathrm{H}_{2} \mathrm{AsO}_{4}\right)_{2}\left(\mathrm{H}_{3} \mathrm{AsO}_{4}\right)_{2}$} & & \multicolumn{5}{|c|}{$\mathrm{Mn}\left(\mathrm{H}_{2} \mathrm{AsO}_{4}\right)_{2}\left(\mathrm{H}_{3} \mathrm{AsO}_{4}\right)_{2}$} & \multicolumn{4}{|c|}{$\mathrm{Co}\left(\mathrm{H}_{2} \mathrm{AsO}_{4}\right)_{2}\left(\mathrm{H}_{3} \mathrm{AsO}_{4}\right)_{2}$} \\
\hline \multirow[t]{4}{*}{ Mg1 } & - & O7 & $2.0680(13)$ & $2 \times$ & Mn1 & - & O7 & $2.1629(9)$ & $2 x$ & Co1 & - $\quad$ O7 & $2.050(3)$ & $2 x$ \\
\hline & - & O5 & $2.0853(14)$ & $2 \times$ & & - & O5 & $2.1707(9)$ & $2 x$ & & O5 & $2.146(3)$ & $2 x$ \\
\hline & - & $\mathrm{O} 3$ & $2.1205(14)$ & $2 \times$ & & - & $\mathrm{O} 3$ & $2.2120(11)$ & $2 x$ & & $\mathrm{O} 3$ & $2.146(4)$ & $2 \times$ \\
\hline & & av. & 2.09 & & & & av. & 2.18 & & & av. & 2.11 & \\
\hline \multirow[t]{5}{*}{ As1 } & - & $\mathrm{O} 3$ & $1.6484(14)$ & & As1 & - & $\mathrm{O} 3$ & $1.6458(10)$ & & As1 & $\mathrm{O} 3$ & $1.650(3)$ & \\
\hline & - & $\mathrm{O} 1$ & $1.6852(14)$ & & & - & O1 & $1.6831(10)$ & & & O1 & $1.687(3)$ & \\
\hline & - & $\mathrm{O} 4$ & $1.6983(16)$ & & & - & $\mathrm{O} 4$ & $1.6983(11)$ & & & $\mathrm{O} 4$ & $1.696(3)$ & \\
\hline & - & $\mathrm{O} 2$ & $1.7096(15)$ & & & - & $\mathrm{O} 2$ & $1.7037(12)$ & & & $\mathrm{O} 2$ & $1.711(4)$ & \\
\hline & & av. & 1.685 & & & & av. & 1.683 & & & av. & 1.686 & \\
\hline \multirow[t]{5}{*}{ As2 } & - & O5 & $1.6562(15)$ & & As2 & - & O5 & $1.6552(9)$ & & As2 & O5 & $1.663(3)$ & \\
\hline & - & O7 & $1.6579(14)$ & & & - & $\mathrm{O} 7$ & $1.6561(9)$ & & & O7 & $1.665(3)$ & \\
\hline & - & O6 & $1.7119(14)$ & & & - & O6 & $1.7076(11)$ & & & O6 & $1.709(4)$ & \\
\hline & - & $\mathrm{O} 8$ & $1.7161(15)$ & & & - & O8 & $1.7131(11)$ & & & O8 & $1.717(4)$ & \\
\hline & & av. & 1.686 & & & & av. & 1.683 & & & av. & 1.689 & \\
\hline \multicolumn{14}{|c|}{$\mathrm{Ni}\left(\mathrm{H}_{2} \mathrm{AsO}_{4}\right)_{2}\left(\mathrm{H}_{3} \mathrm{AsO}_{4}\right)_{2}$} \\
\hline $\mathrm{Ni1}$ & - & O7 & $2.037(3)$ & & & 2 & & & & & & & \\
\hline & - & O5 & $2.097(3)$ & & & 2 & & & & & & & \\
\hline & - & $\mathrm{O} 3$ & $2.117(3)$ & & & 2 & & & & & & & \\
\hline & & av. & 2.08 & & & & & & & & & & \\
\hline As1 & - & $\mathrm{O} 3$ & $1.644(3)$ & & & & & & & & & & \\
\hline & - & $\mathrm{O} 1$ & 1.694(3) & & & & & & & & & & \\
\hline & - & $\mathrm{O} 4$ & $1.696(3)$ & & & & & & & & & & \\
\hline & - & $\mathrm{O} 2$ & $1.712(3)$ & & & & & & & & & & \\
\hline & & av. & 1.689 & & & & & & & & & & \\
\hline As2 & - & O5 & $1.656(3)$ & & & & & & & & & & \\
\hline & - & O7 & $1.664(3)$ & & & & & & & & & & \\
\hline & - & O6 & $1.713(3)$ & & & & & & & & & & \\
\hline & - & $\mathrm{O} 8$ & $1.713(3)$ & & & & & & & & & & \\
\hline & & av. & 1.687 & & & & & & & & & & \\
\hline
\end{tabular}


Table 2. Details of the hydrogen bonding geometry/ $\AA$, ․

\begin{tabular}{|c|c|c|c|c|c|c|}
\hline$D$ & $\mathbf{H}$ & $A$ & $D-H$ & $\mathbf{H} \cdots A$ & $D \cdots A$ & $D-\mathbf{H} \cdots A$ \\
\hline \multicolumn{7}{|c|}{$\mathrm{Mg}\left(\mathrm{H}_{2} \mathrm{AsO}_{4}\right)_{2}\left(\mathrm{H}_{3} \mathrm{AsO}_{4}\right)_{2}$} \\
\hline $\mathrm{O} 2$ & H1 & O8 & $0.890(10)$ & $1.918(18)$ & $2.769(2)$ & $160(4)$ \\
\hline $\mathrm{O} 1$ & $\mathrm{H} 2$ & O7 & $0.898(10)$ & $1.620(11)$ & $2.517(2)$ & $174(4)$ \\
\hline $\mathrm{O} 4$ & H3 & O5 & $0.895(10)$ & $1.758(14)$ & $2.634(2)$ & $167(4)$ \\
\hline O6 & $\mathrm{H} 4$ & O1 & $0.884(10)$ & $1.96(2)$ & $2.760(2)$ & $149(4)$ \\
\hline O8 & H5 & $\mathrm{O} 3$ & $0.893(10)$ & $1.686(11)$ & $2.577(2)$ & $174(4)$ \\
\hline \multicolumn{7}{|c|}{$\mathrm{Mn}\left(\mathrm{H}_{2} \mathrm{AsO}_{4}\right)_{2}\left(\mathrm{H}_{3} \mathrm{AsO}_{4}\right)_{2}$} \\
\hline $\mathrm{O} 2$ & H1 & O8 & $0.890(10)$ & $1.921(11)$ & $2.8018(16)$ & $170(3)$ \\
\hline O1 & $\mathrm{H} 2$ & O7 & $0.898(10)$ & $1.654(13)$ & $2.5358(14)$ & $167(4)$ \\
\hline $\mathrm{O} 4$ & H3 & O5 & $0.895(10)$ & $1.759(12)$ & $2.6452(15)$ & 170(3) \\
\hline O6 & $\mathrm{H} 4$ & O1 & $0.884(10)$ & $1.932(12)$ & $2.7968(14)$ & $166(3)$ \\
\hline O8 & H5 & $\mathrm{O} 3$ & $0.893(10)$ & $1.723(13)$ & $2.6007(14)$ & $167(4)$ \\
\hline \multicolumn{7}{|c|}{$\mathrm{Co}\left(\mathrm{H}_{2} \mathrm{AsO}_{4}\right)_{2}\left(\mathrm{H}_{3} \mathrm{AsO}_{4}\right)_{2}$} \\
\hline $\mathrm{O} 2$ & H1 & O8 & $0.898(10)$ & $1.94(3)$ & $2.812(5)$ & $163(8)$ \\
\hline O1 & $\mathrm{H} 2$ & O7 & $0.901(10)$ & $1.69(3)$ & $2.564(5)$ & $162(8)$ \\
\hline $\mathrm{O} 4$ & H3 & O5 & $0.898(10)$ & $1.75(3)$ & $2.616(5)$ & 162(7) \\
\hline O6 & $\mathrm{H} 4$ & O1 & $0.896(10)$ & $1.94(3)$ & $2.799(4)$ & $159(7)$ \\
\hline O8 & H5 & $\mathrm{O} 3$ & $0.899(10)$ & $1.71(2)$ & $2.592(5)$ & $167(8)$ \\
\hline \multicolumn{7}{|c|}{$\mathrm{Ni}\left(\mathrm{H}_{2} \mathrm{AsO}_{4}\right)_{2}\left(\mathrm{H}_{3} \mathrm{AsO}_{4}\right)_{2}$} \\
\hline $\mathrm{O} 2$ & H1 & O8 & $0.897(10)$ & $1.92(3)$ & $2.762(4)$ & 155(6) \\
\hline $\mathrm{O} 1$ & $\mathrm{H} 2$ & O7 & $0.898(10)$ & $1.629(17)$ & $2.516(4)$ & $169(6)$ \\
\hline $\mathrm{O} 4$ & H3 & O5 & $0.899(10)$ & $1.75(3)$ & $2.610(4)$ & $159(6)$ \\
\hline O6 & $\mathrm{H} 4$ & O1 & $0.897(10)$ & $1.90(2)$ & $2.755(4)$ & $159(6)$ \\
\hline $\mathrm{O} 8$ & H5 & O3 & $0.900(10)$ & $1.658(14)$ & $2.553(4)$ & $172(7)$ \\
\hline \multicolumn{7}{|c|}{$\mathrm{Mn}\left(\mathrm{HAsO}_{4}\right)\left(\mathrm{H}_{3} \mathrm{AsO}_{4}\right)\left(\mathrm{H}_{2} \mathrm{O}\right)_{0.5}$} \\
\hline O1 & & O5 & & & $2.635(4)$ & \\
\hline O4 & & $\mathrm{O} 2$ & & & $2.458(5)$ & \\
\hline O8 & & $\mathrm{O} 4$ & & & $2.633(6)$ & \\
\hline O6 & & OW & & & $2.61(2)$ & \\
\hline O8 & & OW & & & $2.64(2)$ & \\
\hline OW & & $\mathrm{O} 8$ & & & $2.90(2)$ & \\
\hline OW & & O6 & & & $2.92(2)$ & \\
\hline \multicolumn{7}{|c|}{$\mathrm{Cd}\left(\mathrm{HAsO}_{4}\right)\left(\mathrm{H}_{3} \mathrm{AsO}_{4}\right)\left(\mathrm{H}_{2} \mathrm{O}\right)_{0.5}$} \\
\hline O1 & & O5 & & & $2.625(5)$ & \\
\hline $\mathrm{O} 4$ & & $\mathrm{O} 2$ & & & $2.470(5)$ & \\
\hline O8 & & $\mathrm{O} 4$ & & & $2.670(7)$ & \\
\hline O6 & & OW & & & $2.75(4)$ & \\
\hline O8 & & OW & & & $2.60(4)$ & \\
\hline OW & & O6 & & & $2.84(4)$ & \\
\hline OW & & O8 & & & $2.94(4)$ & \\
\hline \multicolumn{7}{|c|}{$\mathrm{Zn}\left(\mathrm{HAsO}_{4}\right)\left(\mathrm{H}_{3} \mathrm{AsO}_{4}\right)$} \\
\hline O1 & & O5 & & & $2.610(6)$ & \\
\hline $\mathrm{O} 4$ & & $\mathrm{O} 2$ & & & $2.429(6)$ & \\
\hline O8 & & O4 & & & $2.666(6)$ & \\
\hline O6 & & O4 & & & $2.962(7)$ & \\
\hline O6 & & O4 & & & $3.071(7)$ & \\
\hline
\end{tabular}

2.2. Crystal Structures of $M\left(H_{A s O}\right)_{4}\left(H_{3} A s O_{4}\right)\left(H_{2} O\right)_{0.5}(M=M n, C d)$ and $\mathrm{Zn}\left(\mathrm{HAsO}_{4}\right)\left(\mathrm{H}_{3} \mathrm{AsO}_{4}\right)$

The $\mathrm{M}\left(\mathrm{HAsO}_{4}\right)\left(\mathrm{H}_{3} \mathrm{AsO}_{4}\right)\left(\mathrm{H}_{2} \mathrm{O}\right)_{0.5}(\mathrm{M}=\mathrm{Mn}, \mathrm{Cd})$ and $\mathrm{Zn}\left(\mathrm{HAsO}_{4}\right)\left(\mathrm{H}_{3} \mathrm{AsO}_{4}\right)$ compounds appeared as the first crystallization products in the strongly acidic aqueous solutions and subsequently converted into the $\mathrm{M}\left(\mathrm{H}_{2} \mathrm{AsO}_{4}\right)_{2}\left(\mathrm{H}_{3} \mathrm{AsO}_{4}\right)_{2}$ compounds after a few days, or to koritnigite $\left(\mathrm{ZnHAsO} \cdot \mathrm{H}_{2} \mathrm{O}\right)$ for the $\mathrm{Zn}$ compound. This behavior indicates a dynamic equilibrium between the double and single deprotonated $\mathrm{HAsO}_{4}{ }^{2-}$ and $\mathrm{H}_{2} \mathrm{AsO}_{4}{ }^{-}$anions and fully protonated $\mathrm{H}_{3} \mathrm{AsO}_{4}$. Apparently, in the first crystallization stage the less acidic $M\left(\mathrm{HAsO}_{4}\right)\left(\mathrm{H}_{3} \mathrm{AsO}_{4}\right)\left(\mathrm{H}_{2} \mathrm{O}\right)_{0.5}(M=\mathrm{Mn}, \mathrm{Cd})$ compounds form, and in the subsequent crystallization stage the higher acidic $M\left(\mathrm{H}_{2} \mathrm{AsO}_{4}\right)_{2}\left(\mathrm{H}_{3} \mathrm{AsO}_{4}\right)_{2}$ compounds. This 
behavior, however, is reversed for the $\mathrm{Zn}$ compounds where the less acidic phase $\mathrm{ZnHAsO}_{4} \cdot \mathrm{H}_{2} \mathrm{O}$ formed as the second crystallization product. Therefore, a clear trend cannot be noticed for these systems.

The two $M\left(\mathrm{HAsO}_{4}\right)\left(\mathrm{H}_{3} \mathrm{AsO}_{4}\right)\left(\mathrm{H}_{2} \mathrm{O}\right)_{0.5}(\mathrm{M}=\mathrm{Mn}, \mathrm{Cd})$ crystal structures are isotypic. All atoms in the asymmetric unit are located on general positions. The $M^{\mathrm{II}}$ cations exhibit a considerably distorted octahedral coordination environment, with bond lengths between 2.14 and $2.23 \AA$ in the Mn structure and between 2.24 and $2.32 \AA$ in the $\mathrm{Cd}$ structure. In contrast to the $M\left(\mathrm{H}_{2} \mathrm{AsO}_{4}\right)_{2}\left(\mathrm{H}_{3} \mathrm{AsO}_{4}\right)_{2}$ structure type $(\mathrm{M}$ :As ratio $=4)$ where isolated $\mathrm{MO}_{6}$ octahedra are linked by bridging dihydrogenarsenate groups into chains, the $\mathrm{MO}_{6}$ octahedra in the $M\left(\mathrm{HAsO}_{4}\right)\left(\mathrm{H}_{3} \mathrm{AsO}_{4}\right)\left(\mathrm{H}_{2} \mathrm{O}\right)_{0.5}$ structure type (M:As ratio 1:2) share edges under formation of undulating centrosymmetric ${ }_{\propto}^{1}\left[M_{4 / 2} \mathrm{O}_{2 / 1}\right]$ chains running parallel (010). As expected, the $\mathrm{Cd}-\mathrm{O}$ bonds are longer (on average about $0.09 \AA$ ) than the Mn-O bonds. $\mathrm{As}_{4} \mathrm{O}_{4}$ tetrahedra share two corners with the $M$ cation within the ${ }_{\propto}^{1}\left[\mathrm{MO}_{4 / 2} \mathrm{O}_{2 / 1}\right]$ chain, and one corner with an $M$ cation in an adjacent chain, thus bridging the chains into layers extending along (001). $\mathrm{As}_{2} \mathrm{O}_{4}$ tetrahedra share only one $\mathrm{O}$ atom with the chain and make up the outer boundary of the layers. A disordered water molecule is situated approximately at $c / 2$ and links neighboring layers along (001) (Figure 2a).
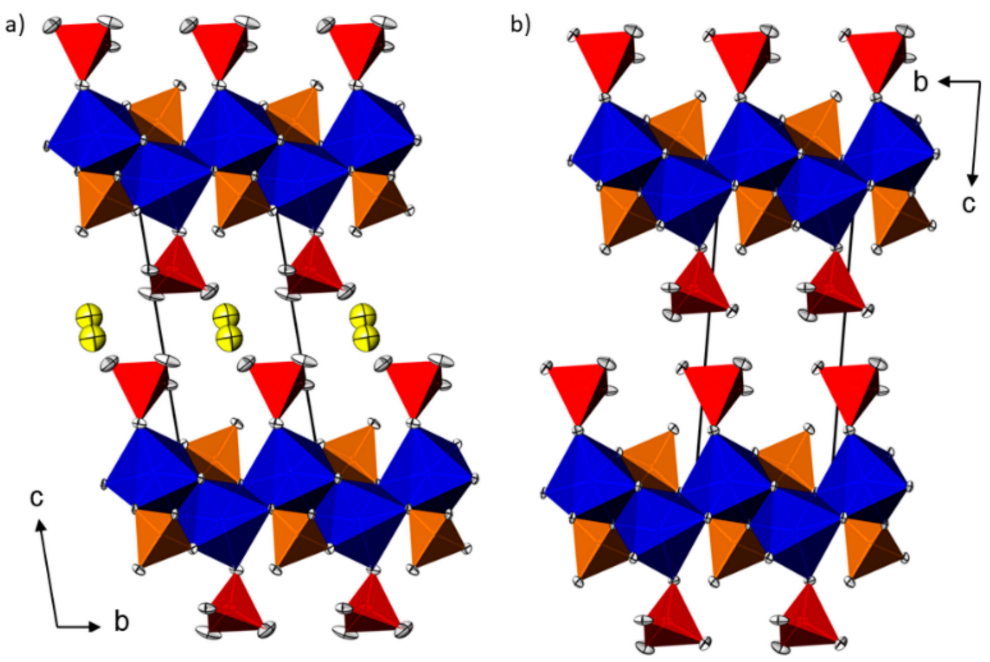

Figure 2. (a) Representative for the two $M\left(\mathrm{HAsO}_{4}\right)\left(\mathrm{H}_{3} \mathrm{AsO}_{4}\right)\left(\mathrm{H}_{2} \mathrm{O}\right)_{0.5}(M=\mathrm{Mn}, \mathrm{Cd})$ compounds, the crystal structure of $\mathrm{Mn}\left(\mathrm{H}_{2} \mathrm{AsO}_{4}\right)_{2}\left(\mathrm{H}_{3} \mathrm{AsO}_{4}\right)_{2}$ is given in a projection along (100); (b) the crystal structure of $\mathrm{Zn}\left(\mathrm{HAsO}_{4}\right)\left(\mathrm{H}_{3} \mathrm{AsO}_{4}\right)$ in a projection along (100). Displacement ellipsoids are drawn at the $50 \%$ probability level. $\mathrm{HAsO}_{4}{ }^{2-}$ tetrahedra (As1) are orange, $\mathrm{H}_{3} \mathrm{AsO}_{4}$ tetrahedra (As2) are red, and $\mathrm{MO}_{6}$ octahedra are blue. Water molecules are yellow, with both possible positions (occupancy 0.5) shown.

The crystal structure of $\mathrm{Zn}\left(\mathrm{HAsO}_{4}\right)\left(\mathrm{H}_{3} \mathrm{AsO}_{4}\right)$ is closely related to that of the water-containing layered crystal structure type of $\mathrm{M}\left(\mathrm{HAsO}_{4}\right)\left(\mathrm{H}_{3} \mathrm{AsO}_{4}\right)\left(\mathrm{H}_{2} \mathrm{O}\right)_{0.5}$. A relation between the crystal structures of $M\left(\mathrm{HAsO}_{4}\right)\left(\mathrm{H}_{3} \mathrm{AsO}_{4}\right)\left(\mathrm{H}_{2} \mathrm{O}\right)_{0.5}$ and $\mathrm{Zn}\left(\mathrm{HAsO}_{4}\right)\left(\mathrm{H}_{3} \mathrm{AsO}_{4}\right)$ is apparent from the similar topological arrangement of structure units (Figure 2 ) and similar lengths of the unit cell axes, with $a \approx 5.0, b \approx 5.4$, $c \approx 13.4 \AA$. However, the unit cell angles in the two types of structures differ considerably, with all three angles $<90^{\circ}$ for the $\mathrm{Zn}$ structure and all three angles $>90^{\circ}$ in the $\mathrm{Mn}$ and $\mathrm{Cd}$ structures. Since it is not possible to transform one of the unit cells into a setting that has comparable axes and angles (all $>90^{\circ}$ or all $<90^{\circ}$ ) to the other unit cell, the given reduced cells (Table 3 ) with $a \leq b \leq \mathrm{c}$ and either with all angles $>90^{\circ}$ or $<90^{\circ}$ were used.

The general set-up within the (001) layers in the two crystal structures is the same. Since $\mathrm{Zn}$ has a smaller ionic radius in comparison with $\mathrm{Mn}$ and $\mathrm{Cd}$ [8], the $\mathrm{Zn}-\mathrm{O}$ distances are the shortest in the ${ }_{\propto}^{1}\left[\mathrm{MO}_{4 / 2} \mathrm{O}_{2 / 1}\right]$ chains. The main difference between the crystal structures is related to the missing water molecule in $\mathrm{Zn}\left(\mathrm{HAsO}_{4}\right)\left(\mathrm{H}_{3} \mathrm{AsO}_{4}\right)$. Here adjacent layers are directly stacked along [001] (Figure 2b). 
Table 3. Details of X-ray data collections and crystal structure refinements.

\begin{tabular}{|c|c|c|c|c|c|c|c|}
\hline Compound & $\begin{array}{c}\mathrm{Mn}\left(\mathrm{HAsO}_{4}\right)_{-}^{-} \\
\left(\mathrm{H}_{3} \mathrm{AsO}_{4}\right)\left(\mathrm{H}_{2} \mathrm{O}\right)_{0.5}\end{array}$ & $\begin{array}{c}\mathrm{Cd}\left(\mathrm{HAsO}_{4}\right)\left(\mathrm{H}_{3} \mathrm{AsO}_{4}\right)- \\
\left(\mathrm{H}_{2} \mathrm{O}\right)_{0.5}\end{array}$ & $\begin{array}{c}\mathrm{Zn}\left(\mathrm{HAsO}_{4}\right)- \\
\left(\mathrm{H}_{3} \mathrm{AsO}_{4}\right)\end{array}$ & $\begin{array}{c}\mathrm{Mg}\left(\mathrm{H}_{2} \mathrm{AsO}_{4}\right)_{2-} \\
\left(\mathrm{H}_{3} \mathrm{AsO}_{4}\right)_{2}\end{array}$ & $\begin{array}{c}\mathrm{Mn}\left(\mathrm{H}_{2} \mathrm{AsO}_{4}\right)_{2-} \\
\left(\mathrm{H}_{3} \mathrm{AsO}_{4}\right)_{2}\end{array}$ & $\begin{array}{c}\mathrm{Co}\left(\mathrm{H}_{2} \mathrm{AsO}_{4}\right)_{2-} \\
\left(\mathrm{H}_{3} \mathrm{AsO}_{4}\right)_{2}\end{array}$ & $\begin{array}{c}\mathrm{Ni}\left(\mathrm{H}_{2} \mathrm{AsO}_{4}\right)_{2}- \\
\left(\mathrm{H}_{3} \mathrm{AsO}_{4}\right)_{2}\end{array}$ \\
\hline$M_{R}$ & 345.82 & 403.28 & 347.24 & 590.07 & 620.70 & 624.69 & 624.47 \\
\hline Temp. $/{ }^{\circ} \mathrm{C}$ & 23 & 23 & 23 & -173 & 23 & 23 & 23 \\
\hline Radiation; $\lambda / \AA$ & \multicolumn{7}{|c|}{ — Mo K $\alpha ; 0.71073$ - } \\
\hline Diffractometer & APEXII CCD & SMART CCD & APEXII CCD & APEXII CCD & APEXII CCD & APEXII CCD & APEXII CCD \\
\hline Crystal size $/ \mathrm{mm}^{3}$ & $0.48 \times 0.18 \times 0.02$ & $0.20 \times 0.15 \times 0.02$ & $0.12 \times 0.12 \times 0.01$ & $0.10 \times 0.06 \times 0.01$ & $0.12 \times 0.09 \times 0.02$ & $0.12 \times 0.06 \times 0.01$ & $0.09 \times 0.06 \times 0.04$ \\
\hline Crystal color; form & light-pink; plate & colorless; plate & colorless; fragment & colorless; plate & light-pink; plate & violet; plate & yellow; plate \\
\hline Space group & $\mathrm{P} 1$ & $\mathrm{P} 1$ & P1 & $\mathrm{P} 1$ & P1 & P1 & $\mathrm{P} 1$ \\
\hline Formula units, $Z$ & 2 & 2 & 2 & 1 & 1 & 1 & 1 \\
\hline$a / \AA$ & $4.9750(10)$ & $5.0188(9)$ & $4.9187(3)$ & $5.4558(3)$ & $5.5602(2)$ & $5.495(3)$ & $5.4297(7)$ \\
\hline$b / \AA$ & $5.4747(11)$ & $5.6180(10)$ & $5.2357(3)$ & $7.3180(4)$ & $7.4100(3)$ & $7.394(4)$ & $7.3308(9)$ \\
\hline$c / \AA$ & $13.603(3)$ & $13.734(2)$ & $12.8459(8)$ & $8.3382(5)$ & $8.4276(4)$ & $8.330(5)$ & $8.2795(10)$ \\
\hline$\alpha /^{\circ}$ & $98.86(3)$ & $99.254(3)$ & $83.987(3)$ & $100.231(2)$ & $100.110(2)$ & $100.604(15)$ & $100.356(5)$ \\
\hline$\beta /^{\circ}$ & $93.63(3)$ & $93.756(3)$ & $81.286(3)$ & $98.614(2)$ & $98.578(2)$ & $97.550(14)$ & $98.088(5)$ \\
\hline$\gamma /{ }^{\circ}$ & $99.09(3)$ & $98.845(3)$ & $80.117(3)$ & $93.022(2)$ & $92.744(2)$ & $92.858(12)$ & $92.982(5)$ \\
\hline$V / \AA^{3}$ & $360.02(13)$ & $376.02(12)$ & $321.09(3)$ & $322.84(3)$ & $337.03(2)$ & $328.8(3)$ & $319.95(7)$ \\
\hline$\mu / \mathrm{mm}^{-1}$ & 10.966 & 11.648 & 14.054 & 10.399 & 10.808 & 11.379 & 11.869 \\
\hline X-ray Dens. $/ \mathrm{g} \cdot \mathrm{cm}^{-3}$ & 3.190 & 3.562 & 3.592 & 3.035 & 3.058 & 3.155 & 3.241 \\
\hline Range $\theta_{\min }-\theta_{\max }$ & $3.87-30.00$ & $3.02-31.06$ & $3.96-30.98$ & $3.79-41.89$ & $2.80-41.52$ & $2.81-31.00$ & $2.53-36.71$ \\
\hline Range $h$ & $-6 \rightarrow 6$ & $-7 \rightarrow 7$ & $-7 \rightarrow 6$ & $-10 \rightarrow 10$ & $-10 \rightarrow 10$ & $-7 \rightarrow 7$ & $-9 \rightarrow 8$ \\
\hline$k$ & $-7 \rightarrow 3$ & $-7 \rightarrow 8$ & $-7 \rightarrow 7$ & $-13 \rightarrow 13$ & $-13 \rightarrow 14$ & $-10 \rightarrow 10$ & $-12 \rightarrow 12$ \\
\hline l & $-19 \rightarrow 19$ & $-19 \rightarrow 19$ & $-18 \rightarrow 18$ & $-15 \rightarrow 15$ & $-15 \rightarrow 15$ & $-12 \rightarrow 11$ & $0 \rightarrow 13$ \\
\hline Meas. refl. & 4677 & 4430 & 7650 & 19986 & 17841 & 4582 & 3000 \\
\hline Indep. refl. & 2087 & 2326 & 2011 & 4436 & 4843 & 2057 & 3000 \\
\hline Obs.refl. $[I>2 \sigma(I)]$ & 1831 & 1996 & 1600 & 3262 & 3767 & 1568 & 2566 \\
\hline$R_{i}$ & 0.0287 & 0.0287 & 0.0461 & 0.0656 & 0.0285 & 0.0364 & - \\
\hline Abs. corr. & SADABS & SADABS & SADABS & SADABS & SADABS & SADABS & TWINABS \\
\hline Trans. coef. $T_{\min } ; T_{\max }$ & $0.526 ; 0.748$ & $0.443 ; 0.663$ & $0.480 ; 0.747$ & $0.531 ; 0.748$ & $0.479 ; 0.748$ & $0.592 ; 0.747$ & $0.257 ; 0.439$ \\
\hline Number of parameters & 104 & 104 & 100 & 113 & 113 & 113 & 114 \\
\hline$R\left[F^{2}>2 \sigma\left(F^{2}\right)\right]$ & 0.0332 & 0.0350 & 0.0380 & 0.0353 & 0.0264 & 0.0380 & 0.0387 \\
\hline$w R 2\left(F^{2}\right.$ all $)$ & 0.1053 & 0.0950 & 0.0994 & 0.0712 & 0.0538 & 0.0850 & 0.0880 \\
\hline Goof & 1.1324 & 1.041 & 1.032 & 1.019 & 1.010 & 1.037 & 1.082 \\
\hline CSD number & 1951017 & 1951013 & 1951019 & 1951015 & 1951016 & 1951014 & 1951018 \\
\hline
\end{tabular}




\subsection{Hydrogen Bonding Schemes}

In contrast to the $M\left(\mathrm{H}_{2} \mathrm{AsO}_{4}\right)_{2}\left(\mathrm{H}_{3} \mathrm{AsO}_{4}\right)_{2}$ crystal structures where the localization of all hydrogen atoms and thus interpretation of the hydrogen bonds were unproblematic (Table 2), a clear assignment of the hydrogen bonding scheme was not possible for the $M\left(\mathrm{HAsO}_{4}\right)\left(\mathrm{H}_{3} \mathrm{AsO}_{4}\right)\left(\mathrm{H}_{2} \mathrm{O}\right)_{0.5}$ and $\mathrm{Zn}\left(\mathrm{HAsO}_{4}\right)\left(\mathrm{H}_{3} \mathrm{AsO}_{4}\right)$ structures. Therefore, the bond valence method [9] was used to assign those $\mathrm{O}$ atoms in the three $M\left(\mathrm{HAsO}_{4}\right)\left(\mathrm{H}_{3} \mathrm{AsO}_{4}\right)\left(\mathrm{H}_{2} \mathrm{O}\right)_{0.5}$ and $\mathrm{Zn}\left(\mathrm{HAsO}_{4}\right)\left(\mathrm{H}_{3} \mathrm{AsO}_{4}\right)$ structures that most probably carry a hydrogen atom. For all $M^{\mathrm{II}}-\mathrm{O}$ bonds, the values of Brese and $\mathrm{O}^{\prime}$ Keeffe [10] were applied, and for $\mathrm{As}^{\mathrm{V}} \mathrm{-O}$ bonds the values by Gangé and Hawthorne [11]. Results of the bond valence sum (BVS) calculations are listed in Table 1 and indicate the following atoms as the most probable donor groups, because they have the lowest bond valence sums ( $\leq 1.3$ valence units) of all oxygen atoms: $\mathrm{O} 1$ bonded to As1, and $\mathrm{O} 4, \mathrm{O} 6$ and $\mathrm{O} 8$ bonded to As2. All other $\mathrm{O}$ atoms have considerably higher bond valence sums between 1.5 and 2.0 valence units.

In analogy with the crystal-chemical features of $\mathrm{M}\left(\mathrm{H}_{2} \mathrm{AsO}_{4}\right)_{2}\left(\mathrm{H}_{3} \mathrm{AsO}_{4}\right)_{2}$ where the $\mathrm{OH}$ groups of the $\mathrm{AsO}_{4}$ tetrahedra do not bond to the metal cations, all four assigned $\mathrm{OH}$ groups are bonded solely to arsenic as part of an $\mathrm{AsO}_{4}$ tetrahedron and also show the longest $\mathrm{As}-\mathrm{O}$ bonds in the two types of tetrahedra. Therefore, As1 represents a $\mathrm{HAsO}_{4}{ }^{-}$anion and As2 the fully protonated acid, in accordance with charge neutrality of the overall structure. Analysis of the $\mathrm{O} \cdots \mathrm{O}$ distances around the four $\mathrm{OH}$ groups/(disordered) water molecules revealed hydrogen bonds with possible acceptor atoms listed in Table 2. This includes a very strong hydrogen bond between $\mathrm{O} 4$ and $\mathrm{O} 2$ with an $\mathrm{O} \cdots \mathrm{O}$ distance of $\approx 2.44 \AA$, and other strong hydrogen bonds between 2.60 and $2.65 \AA$ for $D \cdots A$ contacts. The formation of these hydrogen bonds is also reflected in the BVS values of the acceptor $\mathrm{O}$ atoms that do not carry a hydrogen atom themselves. $\mathrm{O} 2$ and O5 are considerably undersaturated (BVS between 1.5 and 1.8 valence units) but are the acceptor atoms of the strongest hydrogen bonds (Table 2). On the other hand, oxygen atoms $\mathrm{O} 3$ and $\mathrm{O} 7$ are saturated with BVS values of 2.0 valence units and do not take part in any hydrogen bonding interaction. In case the water molecule is involved in hydrogen bonding, the hydrogen bonds become weaker $(D \cdots A: 2.60-2.92$ $\AA)$. The weakest hydrogen bond is developed in $\mathrm{Zn}\left(\mathrm{HAsO}_{4}\right)\left(\mathrm{H}_{3} \mathrm{AsO}_{4}\right)$ between $\mathrm{O} 6$ and $\mathrm{O} 4(3.07 \AA)$, connecting two adjacent layers long [001]. Supposed hydrogen bonds for the $M\left(\mathrm{HAsO}_{4}\right)\left(\mathrm{H}_{3} \mathrm{AsO}_{4}\right)\left(\mathrm{H}_{2} \mathrm{O}\right)_{0.5}$ and $\mathrm{Zn}\left(\mathrm{HAsO}_{4}\right)\left(\mathrm{H}_{3} \mathrm{AsO}_{4}\right)$ structures are illustrated in Figure 3. The various possibilities for hydrogen bonding in the two types of structures make it seem likely that parts of the hydrogen atoms are disordered and thus could not unambiguously be located in difference Fourier syntheses.

a)

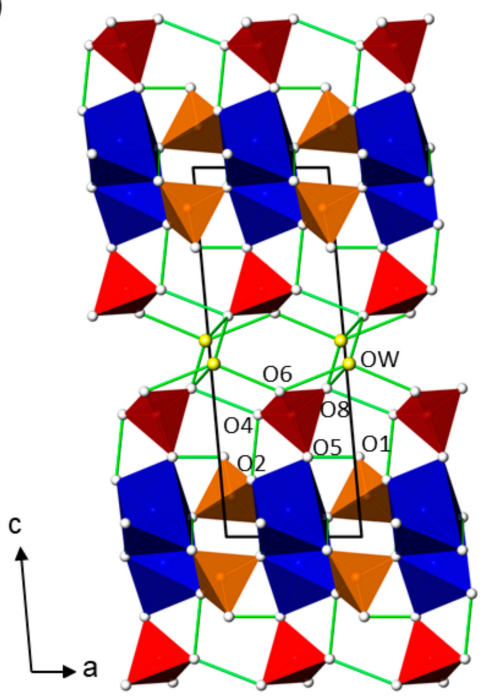

b)

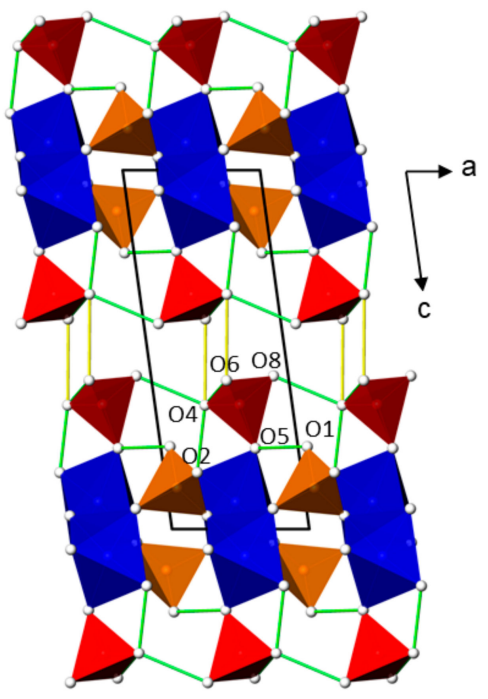

Figure 3. (a) Possible hydrogen bonding schemes in the crystal structures of $\mathrm{Mn}\left(\mathrm{HAsO}_{4}\right)\left(\mathrm{H}_{3} \mathrm{AsO}_{4}\right)\left(\mathrm{H}_{2} \mathrm{O}\right)_{0.5}$ ((a); projection along [010]) and $\mathrm{Zn}\left(\mathrm{HAsO}_{4}\right)\left(\mathrm{H}_{3} \mathrm{AsO}_{4}\right)((\mathbf{b})$; projection along [010]). Hydrogen bonds with $D \cdots A$ contacts $<3.0 \AA$ are given as green lines, and those $>3.0 \AA$ as yellow lines. Color code as in Figure 2. 


\section{4. $\mathrm{AsO}_{4}$ Tetrahedra in the Sructures}

The averaged As-O bond lengths for each $\mathrm{AsO}_{4}$ tetrahedron in the refined structures are collated in Table 1. Individual averaged values scatter only slightly (range 1.677 to $1.689 \AA$ ), and the overall mean of the 14 independent tetrahedral $\mathrm{AsO}_{4}$ groups in the seven structures is $1.685 \AA$, a value in very good agreement with that of $1.687 \AA$ reported in literature [12]. Very recently, a statistical evaluation of As-O bond lengths in $\mathrm{AsO}_{4}{ }^{3-}, \mathrm{HAsO}_{4}{ }^{2-}, \mathrm{H}_{2} \mathrm{AsO}_{4}{ }^{-}$and $\mathrm{H}_{3} \mathrm{AsO}_{4}$ groups was published [13], revealing the following average values: $1.667(18) \AA$ for $\mathrm{As}-\mathrm{O}$ bonds to nonprotonated $\mathrm{O}$ atoms, $1.728(19) \AA$ for As-OH bonds in $\mathrm{HAsO}_{4}{ }^{2-}$ groups, 1.714 (12) $\AA$ for As-OH bonds in $\mathrm{H}_{2} \mathrm{AsO}_{4}{ }^{-}$groups and 1.694(16) $\AA$ for As- $\mathrm{OH}$ bonds in $\mathrm{H}_{3} \mathrm{AsO}_{4}$ groups. These values are in very good agreement with corresponding values for averaged As-OH bond lengths in the four $M\left(\mathrm{H}_{2} \mathrm{AsO}_{4}\right)_{2}\left(\mathrm{H}_{3} \mathrm{AsO}_{4}\right)_{2}$ structures: $M=\mathrm{Mg}$, $1.698 \AA$ for the $\mathrm{H}_{3} \mathrm{AsO}_{4}$ group and $1.714 \AA$ for the $\mathrm{H}_{2} \mathrm{AsO}_{4}{ }^{-}$group; $M=\mathrm{Mn}, 1.695$ and $1.710 \AA$; $M=\mathrm{Co}, 1.698$ and $1.713 \AA ; M=\mathrm{Ni}, 1.701$ and $1.713 \AA$. On the other hand, comparison of the averaged As-OH bond lengths [13] with those of the assigned $\mathrm{HAsO}_{4}{ }^{2-}$ and $\mathrm{H}_{3} \mathrm{AsO}_{4}$ groups in the structures of $M\left(\mathrm{HAsO}_{4}\right)\left(\mathrm{H}_{3} \mathrm{AsO}_{4}\right)\left(\mathrm{H}_{2} \mathrm{O}\right)_{0.5}$ and $\mathrm{Zn}\left(\mathrm{HAsO}_{4}\right)\left(\mathrm{H}_{3} \mathrm{AsO}_{4}\right)$ shows some subtle differences. Both literature values for As-OH in a $\mathrm{HAsO}_{4}{ }^{2-}(1.728(19) \AA)$ and a $\mathrm{H}_{3} \mathrm{AsO}_{4}$ group (1.694(16) $\AA$ ) are slightly larger than corresponding values in the three structures $(\mathrm{Mn}=1.708,1.688 \AA$; $\mathrm{Cd}=1.714,1.686 \AA$, $\mathrm{Zn}=1.710,1.686 \AA$ ). Nevertheless, individual values match the literature values within the single standard deviation of the latter. These slight differences might also indicate some disorder of the hydrogen atoms, as already suspected in Section 2.3.

\subsection{Comparison of the Crystal Structures}

For a quantitative comparison of the isotypic crystal structures within the $M\left(\mathrm{H}_{2} \mathrm{XO}_{4}\right)_{2}\left(\mathrm{H}_{3} \mathrm{XO}_{4}\right)_{2}$ series $(M=\mathrm{Mg}, \mathrm{Mn}, \mathrm{Co}, \mathrm{Ni}, \mathrm{Cu} ; \mathrm{X}=\mathrm{As}, \mathrm{P})$ and between the two isotypic structures of $M\left(\mathrm{HAsO}_{4}\right)\left(\mathrm{H}_{3} \mathrm{AsO}_{4}\right)\left(\mathrm{H}_{2} \mathrm{O}\right)_{0.5}(M=\mathrm{Mn}, \mathrm{Cd})$, respectively, the program compstru [7] available at the Bilbao Crystallographic Server [14] was used. Due to different treatments of $\mathrm{H}$ atoms in the various refinements, e.g., by constrains/restrains regarding $\mathrm{O}-\mathrm{H}$ bond lengths, the comparisons do not include hydrogen atoms.

$\mathrm{Zn}\left(\mathrm{H}_{2} \mathrm{AsO}_{4}\right)_{2}\left(\mathrm{H}_{3} \mathrm{AsO}_{4}\right)_{2}$ was chosen as a reference to which all structures in the $M\left(\mathrm{H}_{2} \mathrm{XO}_{4}\right)_{2}\left(\mathrm{H}_{3} \mathrm{XO}_{4}\right)_{2}$ series were compared. As can be seen from the numerical details of the comparisons compiled in Table 4, the crystal structures of $\mathrm{Zn}\left(\mathrm{H}_{2} \mathrm{AsO}_{4}\right)_{2}\left(\mathrm{H}_{3} \mathrm{AsO}_{4}\right)_{2}$ and its $\mathrm{Mg}, \mathrm{Co}$, and $\mathrm{Ni}$ analogues show a very high similarity $(\Delta<0.02)$ due to similar ionic radii of the four metal cations. Except for the $\mathrm{Mg}$ member for which data were recorded at $-173^{\circ} \mathrm{C}$, all other crystals were measured at room temperature. The minor effect of the temperature on $M-\mathrm{O}$ and $\mathrm{As}-\mathrm{O}$ bond lengths is neglected. $\mathrm{Mn}$ with its greater ionic radius leads to a somewhat larger difference $(\Delta=0.033)$. Likewise, substitution of the arsenate groups by smaller phosphate tetrahedra ( $\mathrm{Co}-\mathrm{P})$ affects the displacements between comparable atomic pairs. Although individual displacement values reach up to $0.17 \AA$ for some $\mathrm{O}$ atoms, $\Delta$ amounts to only 0.037 and thus indicates a high similarity of the two structures. The most remarkable change, however, pertains to the $\mathrm{Cu}$ member $(\Delta=0.112)$. Here the highest displacement is nearly $0.7 \AA$ for atom $\mathrm{O} 3$ that represents the axially bound $\mathrm{O}$ atom in the $\mathrm{MO}_{6}$ octahedron. Due to the Jahn-Teller effect associated with the copper(II) cation, the $\mathrm{CuO}_{6}$ octahedron distorts under considerable elongation of the axial $\mathrm{Cu}-\mathrm{O} 3$ bond.

The compstru program was also used to check the relationship between the $M\left(\mathrm{H}_{2} \mathrm{XO}_{4}\right)_{2}\left(\mathrm{H}_{3} \mathrm{XO}_{4}\right)_{2}$ structure type and the crystal structure of $\mathrm{CdH}_{10}\left(\mathrm{AsO}_{4}\right)_{4}$. The latter crystallizes likewise in space group $P-1$ with one formula unit, has the metal cation situated on an inversion center (Wyckoff position $1 a$ ) and exhibits similar lattice parameters, $a=5.69(5), b=7.42(4), c=8.60(6) \AA, \alpha=105.17(12)$, $\beta=95.13(5), \gamma=91.85(8)^{\circ}$ [4]. The evaluation of structural similarity revealed very large displacements between corresponding atomic pairs. For example, the two types of As atoms in the crystal structures have displacements of 1.71 and $1.97 \AA$, respectively, and for some oxygen atom displacements $>2.0 \AA$ were calculated. Hence the crystal structures of $\mathrm{CdH}_{10}\left(\mathrm{AsO}_{4}\right)_{4}$ and $M\left(\mathrm{H}_{2} \mathrm{XO}_{4}\right)_{2}\left(\mathrm{H}_{3} \mathrm{XO}_{4}\right)_{2}$ cannot be considered as isotypic, as already suggested in [5], but can be regarded as isopointal [15]. 
Comparison of the two isotypic $M\left(\mathrm{HAsO}_{4}\right)\left(\mathrm{H}_{3} \mathrm{AsO}_{4}\right)\left(\mathrm{H}_{2} \mathrm{O}\right)_{0.5}$ structures again shows a high degree of similarity between them. Notable differences with displacements between 0.1 and $0.2 \AA$ affect atom pairs $\mathrm{O} 5$ and $\mathrm{O} 6$ of the $\mathrm{H}_{3} \mathrm{AsO}_{4}$ tetrahedron, and the water molecule (Table 4).

Table 4. Numerical details from the comparisons of the crystal structure of $\mathrm{Zn}\left(\mathrm{H}_{2} \mathrm{AsO}_{4}\right)_{2}\left(\mathrm{H}_{3} \mathrm{AsO}_{4}\right)_{2}$ a with isotypic structures in the $M\left(\mathrm{H}_{2} \mathrm{XO}_{4}\right)_{2}\left(\mathrm{H}_{3} X \mathrm{O}_{4}\right)_{2}$ series $(M=\mathrm{Mg}, \mathrm{Mn}, \mathrm{Co}, \mathrm{Ni}, \mathrm{Cu} ; \mathrm{X}=\mathrm{As}, \mathrm{P})$, and between $\mathrm{Mn}\left(\mathrm{HAsO}_{4}\right)\left(\mathrm{H}_{3} \mathrm{AsO}_{4}\right)\left(\mathrm{H}_{2} \mathrm{O}\right)_{0.5}$ and $\mathrm{Cd}\left(\mathrm{HAsO}_{4}\right)\left(\mathrm{H}_{3} \mathrm{AsO}_{4}\right)\left(\mathrm{H}_{2} \mathrm{O}\right)_{0.5}$ using the compstru program [7].

\begin{tabular}{|c|c|c|c|c|c|c|}
\hline \multicolumn{7}{|c|}{$\mathrm{Zn}\left(\mathrm{H}_{2} \mathrm{AsO}_{4}\right)_{2}\left(\mathrm{H}_{3} \mathrm{AsO}_{4}\right)_{2}$ versus $\mathrm{M}\left(\mathrm{H}_{2} \mathrm{AsO}_{4}\right)_{2}\left(\mathrm{H}_{3} \mathrm{AsO}_{4}\right)_{2}$} \\
\hline$M 1$ & Mg & Mn & $(\mathrm{Co}, \mathrm{P})^{\mathrm{b}}$ & (Co,As) & $\mathbf{N i}$ & $\mathrm{Cu}^{\mathrm{c}}$ \\
\hline \multicolumn{7}{|l|}{ Atom, atomic displacement $|\mathrm{u}| / \AA$} \\
\hline Zn1/M1 & 0 & 0 & 0 & 0 & 0 & 0 \\
\hline As1/As1(P1) & 0.0111 & 0.0289 & 0.0746 & 0.0077 & 0.0200 & 0.3198 \\
\hline As2/As2(P2) & 0.0176 & 0.0434 & 0.0852 & 0.0041 & 0.0122 & 0.1569 \\
\hline $\mathrm{O} 1$ & 0.0242 & 0.0737 & 0.1646 & 0.0134 & 0.0394 & 0.2641 \\
\hline $\mathrm{O} 2$ & 0.0241 & 0.0305 & 0.1641 & 0.0165 & 0.0285 & 0.3981 \\
\hline O3 & 0.0295 & 0.0500 & 0.1157 & 0.0272 & 0.0508 & 0.6942 \\
\hline $\mathrm{O} 4$ & 0.0253 & 0.0353 & 0.0889 & 0.0206 & 0.0184 & 0.2552 \\
\hline O5 & 0.0386 & 0.0497 & 0.1497 & 0.0185 & 0.0129 & 0.0974 \\
\hline O6 & 0.0230 & 0.0384 & 0.0669 & 0.0100 & 0.0337 & 0.2862 \\
\hline O7 & 0.0061 & 0.0807 & 0.1612 & 0.0051 & 0.0266 & 0.3203 \\
\hline $\mathrm{O} 8$ & 0.0295 & 0.0165 & 0.1616 & 0.0224 & 0.0308 & 0.3185 \\
\hline degree of lattice distortion (S) & 0.0049 & 0.0078 & 0.0176 & 0.0030 & 0.0046 & 0.0243 \\
\hline arithmetic mean $\left(\mathrm{d}_{\mathrm{av}}\right)$ & 0.0218 & 0.0426 & 0.1174 & 0.0139 & 0.0260 & 0.2963 \\
\hline measure of similarity $(\Delta)$ & 0.014 & 0.033 & 0.037 & 0.017 & 0.011 & 0.112 \\
\hline
\end{tabular}

\begin{tabular}{cc}
\hline \multicolumn{2}{c}{$\mathbf{M n}\left(\mathrm{HAsO}_{4}\right)\left(\mathrm{H}_{3} \mathrm{AsO}_{4}\right)\left(\mathrm{H}_{2} \mathrm{O}\right)$} \\
\hline Atom, atomic displacement $|\mathrm{u}| / \AA$ & \\
$\mathrm{Mn} 1 / \mathrm{Cd} 1$ & 0.0576 \\
$\mathrm{As} 1$ & 0.0523 \\
$\mathrm{As} 2$ & 0.0816 \\
$\mathrm{O} 1$ & 0.0540 \\
$\mathrm{O} 2$ & 0.0835 \\
$\mathrm{O} 3$ & 0.0492 \\
$\mathrm{O} 4$ & 0.0645 \\
$\mathrm{O} 5$ & 0.1206 \\
$\mathrm{O} 6$ & 0.1899 \\
$\mathrm{O} 7$ & 0.0747 \\
$\mathrm{O} 8$ & 0.0497 \\
OW & 0.1435 \\
degree of lattice distortion $(\mathrm{S})$ & 0.0095 \\
arithmetic mean $\left(\mathrm{d}_{\mathrm{av}}\right)$ & 0.0851 \\
measure of similarity $(\Delta)$ & 0.037
\end{tabular}

a Lattice parameters: $a=5.460(2), b=\AA 7.389(1), c=8.347(1) \AA, \alpha=100.83(4), \beta=97.90(4), \gamma=92.89(3)^{\circ} .{ }^{b}$ Standardized [16] lattice parameters: $a=5.286(2), b=7.195(4), c=8.121(4) \AA, \alpha=101.10(4), \beta=96.72(3), \gamma=92.97(3)^{\circ}$. ${ }^{c}$ Lattice parameters: $a=5.392(3) \AA, b=7.632(4) \AA, c=8.298(5) \AA, \alpha=105.87(4)^{\circ}, \beta=97.63(3)^{\circ}, \gamma=93.6(1)^{\circ}$.

\section{Materials and Methods}

\subsection{Synthesis and Crystal Growth}

The chemicals used $\left(\mathrm{MnCO}_{3}, \mathrm{CdCO}_{3}, \mathrm{ZnO}, \mathrm{Mg}(\mathrm{OH})_{2}, \mathrm{CoCO}_{3} \cdot x \mathrm{H}_{2} \mathrm{O}, \mathrm{NiCO}_{3}, \mathrm{H}_{3} \mathrm{AsO}_{4}\right)$ were of pro analysi quality. The target compounds were prepared by treating the corresponding metal carbonate, oxide or hydroxide with an excess of concentrated arsenic acid (80 wt \%); the employed molar ratio $\mathrm{H}_{3} \mathrm{AsO}_{4}$ :metal precursor was $\approx 10: 1$. The solid metal precursors were added in small portions to the acid and warmed (ca. $70^{\circ} \mathrm{C}$ ) until a clear solution was obtained overnight. In case the metal precursor dissolution was incomplete, the suspension was filtered through a G4 glass frit. All solutions were then 
left at room temperature in a desiccator filled with concentrated sulfuric acid until the first crystals appeared. The crystallization process lasted at least about one week; yields were not determined.

All grown crystals of the $M\left(\mathrm{H}_{2} \mathrm{AsO}_{4}\right)_{2}\left(\mathrm{H}_{3} \mathrm{AsO}_{4}\right)_{2}(M=\mathrm{Mg}, \mathrm{Co}, \mathrm{Ni})$ phases had a plate-like form and were directly taken out of the mother liquor. $\mathrm{Cd}\left(\mathrm{HAsO}_{4}\right)\left(\mathrm{H}_{3} \mathrm{AsO}_{4}\right)\left(\mathrm{H}_{2} \mathrm{O}\right)_{0.5}$ crystallized in form of thin plates and was the first crystallisation product from the solution. After a few days, these crystals converted in the mother liquor into coarse-crystalline $\mathrm{CdH}_{10}\left(\mathrm{AsO}_{4}\right)_{4}$ [4]. Likewise, $\mathrm{Mn}\left(\mathrm{HAsO}_{4}\right)\left(\mathrm{H}_{3} \mathrm{AsO}_{4}\right)\left(\mathrm{H}_{2} \mathrm{O}\right)_{0.5}$ crystals were the first crystallization product and converted over the course of a few days into $\mathrm{Mn}\left(\mathrm{H}_{2} \mathrm{AsO}_{4}\right)_{2}\left(\mathrm{H}_{3} \mathrm{AsO}_{4}\right)_{2}$. $\mathrm{Zn}\left(\mathrm{HAsO}_{4}\right)\left(\mathrm{H}_{3} \mathrm{AsO}_{4}\right)$ crystals appeared with an unspecific form together with synthetic koritnigite $\left(\mathrm{ZnHAsO}_{4} \cdot \mathrm{H}_{2} \mathrm{O}\right.$ [17]; platy crystals). The amount of the latter phase increased in the remaining mother liquor over time.

\subsection{Single Crystal X-ray Diffraction}

Since all crystals appeared to be highly hygroscopic, they were immediately immersed in perfluorinated oil (FomblinßY, Sigma-Aldrich, Taufkirchen, Germany) and optically preselected under a polarizing microscope. The diffraction studies (Mo K $\alpha$ radiation; Bruker SMART CCD or APEX-II CCD diffractometer; Bruker-AXS Inc. (Madison, WI, USA) followed standard procedures, including absorption corrections based on a multi-scan approach [18,19]. All crystal structures were solved with SHELXT [20] and refined with SHELXL [21]. The diffraction pattern of $\mathrm{Ni}\left(\mathrm{H}_{2} \mathrm{AsO}_{4}\right)_{2}\left(\mathrm{H}_{3} \mathrm{AsO}_{4}\right)_{2}$ revealed a two-domain crystal (arbitrarily intergrown). Intensity data of this crystal were assigned to the two different domains and further processed as a HKLF-5 file; the ratio of the two domains refined to a value of 0.57:0.43. For better comparison, atomic coordinates and atom labels of all $M\left(\mathrm{H}_{2} \mathrm{AsO}_{4}\right)_{2}\left(\mathrm{H}_{3} \mathrm{AsO}_{4}\right)_{2}(M=\mathrm{Mg}, \mathrm{Mn}, \mathrm{Co}, \mathrm{Ni})$ structures were finally adapted to the structure data of $\mathrm{Zn}\left(\mathrm{H}_{2} \mathrm{AsO}_{4}\right)_{2}\left(\mathrm{H}_{3} \mathrm{AsO}_{4}\right)_{2}$ [6]. Likewise, the two new $M\left(\mathrm{HAsO}_{4}\right)\left(\mathrm{H}_{3} \mathrm{AsO}_{4}\right)\left(\mathrm{H}_{2} \mathrm{O}\right)_{0.5}(M=\mathrm{Mn}, \mathrm{Cd})$ structures are described with comparable atomic coordinates and atom labels. In this structure type, conspicuous electron density was observed around an inversion center after modelling the $M\left(\mathrm{HAsO}_{4}\right)\left(\mathrm{H}_{3} \mathrm{AsO}_{4}\right)$ framework. This electron density was assigned to the $\mathrm{O}$ atom of a water molecule of crystallization, disordered around an inversion center. Because the symmetry-related water molecules cannot be occupied at the same time, the occupancy of the water molecule was constrained to 0.5 . For the final model, this atom was refined with an isotropic displacement parameter. In the closely related structure of $\mathrm{Zn}\left(\mathrm{HAsO}_{4}\right)\left(\mathrm{H}_{3} \mathrm{AsO}_{4}\right)$, no such additional electron density was found.

For the $M\left(\mathrm{H}_{2} \mathrm{AsO}_{4}\right)_{2}\left(\mathrm{H}_{3} \mathrm{AsO}_{4}\right)_{2}(\mathrm{M}=\mathrm{Mg}, \mathrm{Mn}, \mathrm{Co}, \mathrm{Ni})$ crystal structures, all hydrogen atoms could clearly be located from difference Fourier syntheses. For refinement, their $\mathrm{H}-\mathrm{O}$ distances were restrained to $0.90(1) \AA$, together with a common $U_{\text {iso }}(\mathrm{H})$ parameter. For the crystal structures of $M\left(\mathrm{HAsO}_{4}\right)\left(\mathrm{H}_{3} \mathrm{AsO}_{4}\right)\left(\mathrm{H}_{2} \mathrm{O}\right)_{0.5}(M=\mathrm{Mn}, \mathrm{Cd})$ and $\mathrm{Zn}\left(\mathrm{HAsO}_{4}\right)\left(\mathrm{H}_{3} \mathrm{AsO}_{4}\right)$, an unambiguous assignment of hydrogen atoms was not possible. Hence, their positions are not included in the final models. Graphical representations of the crystal structures were performed with ATOMS for Windows [22].

Details of numerical values of the data collections and structure refinements are gathered in Table 3 and Supplementary Materials. Further details of the crystal structure investigations may be obtained from The Cambridge Crystallographic Data Centre (CCDC) on quoting the depository numbers listed at the end of Table 3. The data can be obtained free of charge via www.ccdc.cam.ac.uk/structures.

\section{Conclusions}

The oxidoarsenates $(\mathrm{V}) M\left(\mathrm{H}_{2} \mathrm{AsO}_{4}\right)_{2}\left(\mathrm{H}_{3} \mathrm{AsO}_{4}\right)_{2}(\mathrm{M}=\mathrm{Mg}$, $\mathrm{Mn}, \mathrm{Co}, \mathrm{Ni}), M\left(\mathrm{HAsO}_{4}\right)\left(\mathrm{H}_{3} \mathrm{AsO}_{4}\right)\left(\mathrm{H}_{2} \mathrm{O}\right)_{0.5}$ $(M=\mathrm{Mn}, \mathrm{Cd})$ and $\mathrm{Zn}\left(\mathrm{HAsO}_{4}\right)\left(\mathrm{H}_{3} \mathrm{AsO}_{4}\right)$ were crystallized from highly acidic solutions. The results of structure refinements of isotypic $M\left(\mathrm{H}_{2} \mathrm{XO}_{4}\right)_{2}\left(\mathrm{H}_{3} X_{\mathrm{O}_{4}}\right)_{2}(M=\mathrm{Mg}, \mathrm{Mn}, \mathrm{Co}, \mathrm{Ni} ; X=\mathrm{As})$ compounds from single crystal $\mathrm{X}$-ray data supplement the knowledge on this structure type. Quantitative comparisons between all known crystal structures in this series with $M=\mathrm{Mg}, \mathrm{Mn}, \mathrm{Co}, \mathrm{Ni}, \mathrm{Cu}$, $\mathrm{Zn} ; \mathrm{X}=\mathrm{As}$; P revealed a high similarity with the exception for the $(\mathrm{Cu}, \mathrm{As})$ member. The crystal structure of the latter shows considerable distortions due to the Jahn-Teller effect of $\mathrm{Cu}$ (II), leading to a displacement of up to $0.7 \AA$ between related atomic pairs. It was also shown that the isoformular 
compound $\mathrm{CdH}_{10}\left(\mathrm{AsO}_{4}\right)_{4}\left(=\mathrm{Cd}\left(\mathrm{H}_{2} \mathrm{AsO}_{4}\right)_{2}\left(\mathrm{H}_{3} \mathrm{AsO}_{4}\right)_{2}\right)$ is not isotypic with the $\mathrm{M}\left(\mathrm{H}_{2} \mathrm{XO}_{4}\right)_{2}\left(\mathrm{H}_{3} \mathrm{XO}_{4}\right)_{2}$ series, but isopointal. The crystal structures of the two isotypic $M\left(\mathrm{HAsO}_{4}\right)\left(\mathrm{H}_{3} \mathrm{AsO}_{4}\right)\left(\mathrm{H}_{2} \mathrm{O}\right)_{0.5}(M=\mathrm{Mn}$, Cd) compounds and of $\mathrm{Zn}\left(\mathrm{HAsO}_{4}\right)\left(\mathrm{H}_{3} \mathrm{AsO}_{4}\right)$ are closely related. They comprise of $M\left(\mathrm{HAsO}_{4}\right)\left(\mathrm{H}_{3} \mathrm{AsO}_{4}\right)$ layers that are linked through hydrogen-bonded water molecules in the water-containing structures, or directly in the water-free structure. As-O distances in the two types of tetrahedra $\left(\mathrm{HAsO}_{4}{ }^{2-} ; \mathrm{H}_{3} \mathrm{AsO}_{4}\right)$ suggest disorder of the hydrogen atoms that could not be located in the present study.

Supplementary Materials: The following are available online at http://www.mdpi.com/2304-6740/7/10/122/s1, the CIFs and the checkCIF output files for $M\left(\mathrm{H}_{2} \mathrm{AsO}_{4}\right)_{2}\left(\mathrm{H}_{3} \mathrm{AsO}_{4}\right)_{2}(M=\mathrm{Mg}$, Mn, $\mathrm{Co}, \mathrm{Ni}), M\left(\mathrm{HAsO}_{4}\right)\left(\mathrm{H}_{3} \mathrm{AsO}_{4}\right)\left(\mathrm{H}_{2} \mathrm{O}\right)_{0.5}$ $(M=\mathrm{Mn}, \mathrm{Cd})$ and $\mathrm{Zn}\left(\mathrm{HAsO}_{4}\right)\left(\mathrm{H}_{3} \mathrm{AsO}_{4}\right)$.

Funding: This research received no external funding.

Acknowledgments: The X-ray centre of the TU Wien is acknowledged for providing access to the single-crystal and powder X-ray diffractometers.

Conflicts of Interest: The author declares no conflict of interest.

\section{References}

1. Salmon, J.E.; Terrey, H. The systems zinc oxide-phosphoric oxide-water and manganous oxide-phosphoric oxide-water at temperatures between $25^{\circ}$ and $100^{\circ}$. J. Chem. Soc. 1950, 2813-2824. [CrossRef]

2. Herak, R.; Prelesnik, B.; Čurić, M.; Djurić, S. The crystal structure of $\mathrm{Co}\left(\mathrm{H}_{2} \mathrm{PO}_{4}\right)_{2} \cdot 2 \mathrm{H}_{3} \mathrm{PO}_{4}$. Z. Kristallogr. 1983, 164, 25-30. [CrossRef]

3. Averbuch-Pouchot, M.T.; Durif, A. Topics in Phosphate Chemistry; World Scientific: Singapore, 1996; p. 346.

4. Boudjada, A.; Durif, A.; Guitel, J.C. Structure d'un orthoarsenate acide de cadmium: $\mathrm{CdH}_{10}\left(\mathrm{AsO}_{4}\right)_{4}$. Acta Crystallogr. Sect. B 1980, B36, 133-135. [CrossRef]

5. Tran Qui, D.; Chiadmi, M. Structure de Décahydrogénotétraarsenate de Cuivre et Isotypie dans la Série $M^{\mathrm{II}} \mathrm{H}_{10}\left(\mathrm{AsO}_{4}\right)_{4}\left(M^{\mathrm{II}}=\mathrm{Mg}, \mathrm{Mn}, \mathrm{Co}, \mathrm{Ni}\right.$, Cu et $\left.\mathrm{Zn}\right)$. Acta Crystallogr. Sect. C 1986, C42, 391-393. [CrossRef]

6. Sure, S.; Guse, W. The crystal structure of zinc-decahydrogen-tetraarsenate $\mathrm{ZnH}_{10}\left(\mathrm{AsO}_{4}\right)_{4}$. Neues Jahrb. Mineral. Monatsh. 1989, 9, 401-409.

7. De la Flor, G.; Orobengoa, D.; Tasci, E.; Perez-Mato, J.M.; Aroyo, M.I. Comparison of structures applying the tools available at the Bilbao Crystallographic Server. J. Appl. Crystallogr. 2016, 49, 653-664. [CrossRef]

8. Shannon, R.D. Revised effective ionic radii and systematic studies of interatomic distances in halides and chalcogenides. Acta Crystallogr. Sect. A 1976, A32, 751-767. [CrossRef]

9. Brown, I.D. The Chemical Bond in Inorganic Chemistry: The Bond Valence Model; Oxford University Press: Oxford, UK, 2002.

10. Brese, N.E.; O'Keeffe, M. Bond-valence parameters for solids. Acta Crystallogr. Sect. B 1991, B47, 192-197. [CrossRef]

11. Gagné, O.C.; Hawthorne, F.C. Comprehensive derivation of bond-valence parameters for ion pairs involving oxygen. Acta Crystallogr. Sect. B 2015, B71, 562-578. [CrossRef] [PubMed]

12. Gagné, O.C.; Hawthorne, F.C. Bond-length distributions for ions bonded to oxygen: Metalloids and post-transition metals. Acta Crystallogr. Sect. B 2018, B74, 63-78. [CrossRef]

13. Schwendtner, K.; Kolitsch, U. Three new acid $M^{+}$arsenates and phosphates with multiply protonated As $/ \mathrm{PO}_{4}$ groups. Acta Crystallogr. Sect. C 2019, C75, 1134-1141. [CrossRef] [PubMed]

14. Aroyo, M.I.; Perez-Mato, J.M.; Capillas, C.; Kroumova, E.; Ivantchev, S.; Madariaga, G.; Kirov, A.; Wondratschek, H. Bilbao Crystallographic Server I: Databases and crystallographic computing programs. Z. Kristallogr. 2006, 221, 15-27. [CrossRef]

15. Lima-de-Faria, J.; Hellner, E.; Liebau, F.; Makovicky, E.; Parthé, E. Nomenclature of inorganic structure types. Report of the International Union of Crystallography Commission on Crystallographic Nomenclature Subcommittee on the Nomenclature of Inorganic Structure Types. Acta Crystallogr. Sect. A 1990, A46, 1-11. [CrossRef]

16. Gelato, L.M.; Parthé, E. STRUCTURE TIDY-A computer program to standardize crystal structure data. J. Appl. Crystallogr. 1987, 20, 139-143. [CrossRef]

17. Keller, P.; Hess, H.; Riffel, H. Die Kristallstruktur von Koritnigit, $\mathrm{Zn}\left[\mathrm{H}_{2} \mathrm{O} \mid \mathrm{HOAsO}_{3}\right]$. Neues Jahrb. Mineral. Abh. 1980, 138, 316-332. 
18. Krause, L.; Herbst-Irmer, R.; Sheldrick, G.M.; Stalke, D. Comparison of silver and molybdenum microfocus X-ray sources for single-crystal structure determination. J. Appl. Crystallogr. 2015, 48, 3-10. [CrossRef] [PubMed]

19. Sheldrick, G.M. TWINABS; University of Göttingen: Göttingen, Germany, 2012.

20. Sheldrick, G.M. SHELXT-Integrated space-group and crystal-structure determination. Acta Crystallogr. Sect. A 2015, A71, 3-8. [CrossRef] [PubMed]

21. Sheldrick, G.M. Crystal structure refinement with SHELXL. Acta Crystallogr. Sect. C 2015, C71, 3-8.

22. Dowty, Е. Атомs for Windows, Version 6.3; Shape Software: Kingsport, TN, USA, 2006.

(C) 2019 by the author. Licensee MDPI, Basel, Switzerland. This article is an open access article distributed under the terms and conditions of the Creative Commons Attribution (CC BY) license (http://creativecommons.org/licenses/by/4.0/). 